\title{
The Effect of Ferrous Nano-oxide Particles on Physiological Traits and Nutritional Compounds of Soybean (Glycine max L.) Seed
}

\author{
ROGHAYYEH SHEYKHBAGLOU ${ }^{1}$, MOHAMMAD SEDGHI ${ }^{1}$ and BAHRAM FATHI-ACHACHLOUIE ${ }^{2}$ \\ ${ }^{1}$ Department of Agronomy and Plant Breeding, Faculty of Agriculture and Natural Resources, \\ University of Mohaghegh Ardabili, Daneshgah Street, 56199-11367, Ardabil, Iran \\ ${ }^{2}$ Department of Food Science and Technology, Faculty of Agriculture and Natural Resources, \\ University of Mohaghegh Ardabili, Daneshgah Street, 56199-11367, Ardabil, Iran
}

Manuscript received on May 5, 2016; accepted for publication on January 26, 2017

\begin{abstract}
Soybean (Glycine max L.) seed contains amounts of protein, lipid, carbohydrate and mineral elements, which protein and lipid have been known as a main part for soybean's trade value. In this study, in order to investigate the effect of ferrous nano-oxide particles on nutritional compounds of soybean seed, an experiment with 5 treatments and 3 replications was conducted as a randomized complete block design. Treatments were 5 concentrations of ferrous nano-oxide particles including $0,0.25,0.5,0.75$ and $1 \mathrm{~g} \mathrm{~L}^{-1}$ which were sprayed 3 times at 4 and 8 leaves stage and pod initiation. Lipid and protein contents, fatty acids profile, some of mineral elements such as $\mathrm{Fe}, \mathrm{Mg}, \mathrm{Ca}$ and $\mathrm{P}$, chlorophyll a, b and total chlorophyll content were determined. Results showed that solution containing ferrous nano-oxide particles had significant effect on nutritional compounds of soybean seed $(\mathrm{P}<0.01)$ compared to control. The highest content of lipid and protein (25.4 and \%33.8, respectively) observed by applying $0.75 \mathrm{~g} \mathrm{~L}^{-1}$ of ferrous nano-oxide and the lowest content was also in control. Changes in the trends of fatty acids profile (palmitic, oleic, linoleic and linolenic acids), some of mineral elements ( $\mathrm{Fe}, \mathrm{Mg}, \mathrm{Ca}$ and $\mathrm{P}$ ) and chlorophyll contents were similar to lipid and protein levels which by increasing in concentration of ferrous nano-oxide from 0 to $0.75 \mathrm{~g} \mathrm{~L}^{-1}$ all measured parameters also increased, but reduction in all parameters was observed in concentration from 0.75 to $1 \mathrm{~g} \mathrm{~L}^{-1}$. In conclusion, application of 0.75 to $1 \mathrm{~g} \mathrm{~L}^{-1}$ ferrous nano-oxide had the best effect on the nutrient composition of soybean seed.
\end{abstract}

Key words: soybean, ferrous nano-oxide, nutritional compounds of soybean seed, fatty acids profile, chlorophyll.

\section{INTRODUCTION}

Soybean (Glycine max L.) is an annual plant which belongs to Fabaceae family. Soybean contains of protein, lipid, carbohydrate and mineral elements.

Correspondence to: Mohammad Sedghi

E-mail: m_sedghi@uma.ac.ir
Protein and lipid are included most of soybean's commercial value. Soybean's oil is edible that after purification were used in human food products. Soybean seeds have $18 \%$ of oil and its meal used as a protein source for mixing by livestock and poultry feeds (Sedghi et al. 2005). Microelements such as $\mathrm{Fe}, \mathrm{Mn}, \mathrm{Zn}, \mathrm{Cu}$ and $\mathrm{Br}$ are playing important role 
in growth and yield of crops. It is obvious that the moderate use of fertilizers especially microelement containing fertilizers, had increased production per area unit (at least 20\%), and also the grain of wheat and other fertilized crops had higher germination and emergence power in the next year. Enrichment of agricultural products is vital for Iranian society that suffering from deficiency of these elements (Malakouti and Tehrani 2005).

The presence of iron is essential for formation of protochlorophyllide from magnesiumprotoporfyrin complex, because is involved in structure of aminolevulinic acid (ALA) synthase and participates as coenzyme. By decreasing of ALA due to Iron shortage, the containing of protochlorophyllide and chlorophyll were reduced compared with control plants, while the containing of magnesium-protoporfyrin were increased (Mengel 1991). The amount of this enzyme is affected by Iron deficiency. Aminolevulinic acid is involved in synthesis of Chlorophyll and Heme (Mengel 1991).

Morales et al. (1990) reported that number of photosynthetic pigments and percentage of chlorophyll and beta-carotene in sugar beet were significantly decreased under iron deficiency. In iron deficit condition, xanthophyll percentage was increased dramatically (Marschner 1995). Under iron deficiency amount of zeaxanthyn, viloxanthyn and antroxanthyn rises (Marschner 1995).

Ronaghi and Ghasemi-Fasaei (2007) found that soybean plants are sensitive to iron deficiency, but various genotypes of this plant have varied efficiency of iron consumption. The iron usage in soils that have defect of this element can cause to increasing in soybean seed yield. Iron defection in soybean can also cause to negative effect on nitrogen fixation activity (Chonkar and Chandel 1991, Terry and Jolley 1994, Burke et al. 2015).

Some research has been showed that iron oxide nanoparticles caused to enhancement of growth and photosynthesis of peanut. Iron oxide nanoparticles in compared with treatments such as organic fertilizer and iron citrate facilitated the transferring of materials and increased iron transporting to leaves (Liu et al. 2005).

Oil and protein production depend on the quality characteristics of seeds (oil and protein) and grain yield. Morshedi's research (2000) showed that the usage of iron caused to significantly increase in oil and protein in Rape seeds (25\% in oil and 20\% in protein) in compared with control.

In Soya by using of fertilizers containing iron such as Fe-EDDHA, in addition of seed yield's increasing up to $50 \%$, the amount of seed's iron enhanced up to $30 \%$ (Schenkeveld et al. 2008).

The main aims of this experiment were to evaluate the effect of Iron Oxide nanoparticle on nutritional quality and nutrient compounds of soybean seeds.

\section{MATERIALS AND METHODS}

This field experiment was conducted on clay soil in Agricultural Research Station of Urmia University, Iran during 2009-2010 growing season to investigate the effects of nano-iron oxide on nutritional traits of soybean (CV L17, Table I). Urmia is located on the north-west of Iran with $1320 \mathrm{~m}$ altitude, $45^{\circ} 5^{\prime}$ longitude, and $37^{\circ} 32^{\prime}$ latitude. According to soil analysis performed prior to sowing, $\mathrm{pH}$ of soil was 7.6, and electrical conductivity (EC) of extract was $1.1 \mathrm{ds} . \mathrm{m}^{-1}$ and soil texture was clay. The experimental design was randomized complete block design with three replications. Treatments were control (without nano-iron oxide application) and 4 levels of nanoiron oxide application including $0.25,0.5,0.75$ and $1 \mathrm{~g} \mathrm{lit}^{-1}$. The charateristics of nano-iron oxide used in experiment was shown in Table II. Soybean seeds were inoculated with Bradyrhizobium japonicum before planting.

Nano-iron oxide were sprayed at three stages including 4 leaves, 8 leaves (V8) and grain filling 
TABLE I

Characteristics of soybean cultivar (L17) which used in the experiment.

\begin{tabular}{cc}
\hline Maturity group & III \\
Released & Decade 90 \\
Seed size & Medium \\
Seed color & Yellow \\
Hilum color & Black \\
Flower color & white \\
\hline & TABLE II \\
Characteristics of Fe $\mathbf{O}_{3}$ Nanopowder used in the \\
experiment. \\
\hline Weight \\
Purity
\end{tabular}

stage (R4). Seeds were transported to laboratory after harvesting and chemical analysis performed as below:

\section{CHEMICAL ANALYSIS OF SOYBEAN TREATED SEEDS}

All of solvents and chemicals which used in this experiment were provided from Merck Co (Darmstadt, Germany).

\section{DETERMINATION OF OIL CONTENTS}

For getting the amount of lipid that existent in seeds, first $1 \mathrm{~g}$ of sample was grinded and second homogeneous was divided into test tubes that before were weigh. In order to oil extraction $5 \mathrm{~mL}$ of diethyl ether were added to test tubes containing of samples. Tubes were placed in Eurosonic $4 D$ Ultrasonic set in terms $12 \mathrm{~min}$ at $60{ }^{\circ} \mathrm{C}$. Then tubes were centrifuged at $3000 \mathrm{rpm}$ and after sedimentation, the upper lucid part of solvent removed by pipette and transferred to another tubes with certain weight. These steps were repeated 2 times again. The extracted solvent by this method were dried by nitrogen gas under the fume hood and were weigh again. Difference between weights of empty tubes and tubes containing extracted materials were recorded as extracted lipid from 1 gram of sample $\left(\mathrm{mg} \mathrm{g}^{-1}\right)$ and were reported as lipid percentage.

\section{DETERMINATION OF PROTEIN CONTENTS}

For getting percentage of storage protein in seeds we used autokjeldahl device (Auto Kjeltec, Sweden K Unit Analyser 3700 BUCHI) (Anonymous 2014).

\section{DETERMINATION OF AMOUNT OF MACRO ELEMENTS}

For measurement of iron, calcium, magnesium and phosphorous that are exist in soybean seeds, 200 grams of seeds belong to each treatments were grinded separately. Then powdered samples were putted in electrical furnace at 550 degree centigrade for four hours until white ash was obtained (AOAC 1990). The amount of phosphorous of each sample was determined by colorimetric measurement. The other mineral elements were measured by Atomic Absorption Spectrometer (Perkin Elmer 460, made in USA) (Lindsay and Norvell 1978).

\section{DETERMINATION OF CHLOROPHYLL CONTENT}

In order to measurement of chlorophyll, first $0.1 \mathrm{~g}$ of seed was grinded and mixed by $10 \mathrm{~mL}$ of acetone $80 \%$. Then the solutions were centrifuged at 2700 rpm for five minutes (Mikro22R, made in Germany). Finally were transferred to spectrophotometer (Perkim-Elmer Lambada 25 double beam uv-vis) and the absorbance measured at three wavelengths of 470, 663 and $647 \mathrm{~nm}$. The recorded data were pasted in respective formulas in Lichtenthaler (1987) method to obtain the amount of chlorophyll $\mathrm{a}, \mathrm{b}$ and total of it account of milligram in gram compass ( $\mathrm{mg} \mathrm{g}^{-1}$ ) (Lichtenthaler 1987). 


\section{OIL EXTRACTION FOR ANALYSIS OF FATTY ACIDS}

The process of oil extraction was performed according to Fathi-Achachlouei and AzadmardDamirchi method (2009).

\section{MEASUREMENTS OF FATTY ACIDS}

Preparation of derivative methyl ester from fatty acids and analysis of them by Gas Chromatography was perform according to Azadmard-Damirchi and Dutta's method (2008). To this end, we used a gas chromatography equipped with siliconic capillary column with $50 \mathrm{~cm}$ in length, $0.22 \mathrm{~mm}$ in diameter and $0.25 \mu \mathrm{m}$ in film thickness. The primary temperature was $50{ }^{\circ} \mathrm{C}$ for $2 \mathrm{~min}$, and then temperature was increased up to $158{ }^{\circ} \mathrm{C}$ and $220{ }^{\circ} \mathrm{C}$ by rate of $10{ }^{\circ} \mathrm{C}$ per min and $2{ }^{\circ} \mathrm{C}$ per min respectively. Also injection to $\mathrm{GC}$ was performed in Split way.

\section{STATISTICAL ANALYSIS}

Analysis of correlation and regression coefficients were accomplished with SPSS software and experimental data were fitted in third-degree polynomial model that is an appropriate model. Finally diagrams were drawn by Excel 2007.

\section{RESULTS AND DISCUSSION}

The results of regression analysis of data related to percentages of proteins, lipids and fatty acids amount were shown in Table III. The effect of iron oxide nanoparticles treatment on percentage of protein, lipid and fatty acids included linoleic acid, palmitic acid, oleic acid and linolenic acid were significant at the $1 \%$ of probability level.

The highest percentage of seed's protein was obtained in $0.75 \mathrm{~g} \mathrm{~L}^{-1}$ that has significantly difference with other treatments and witness whereas the least percentage of protein amounts was belong to control (27.53\%). The foliar spraying of soybean with nano- $\mathrm{Fe}_{2} \mathrm{O}_{3}$ justifies the $95 \%$ of

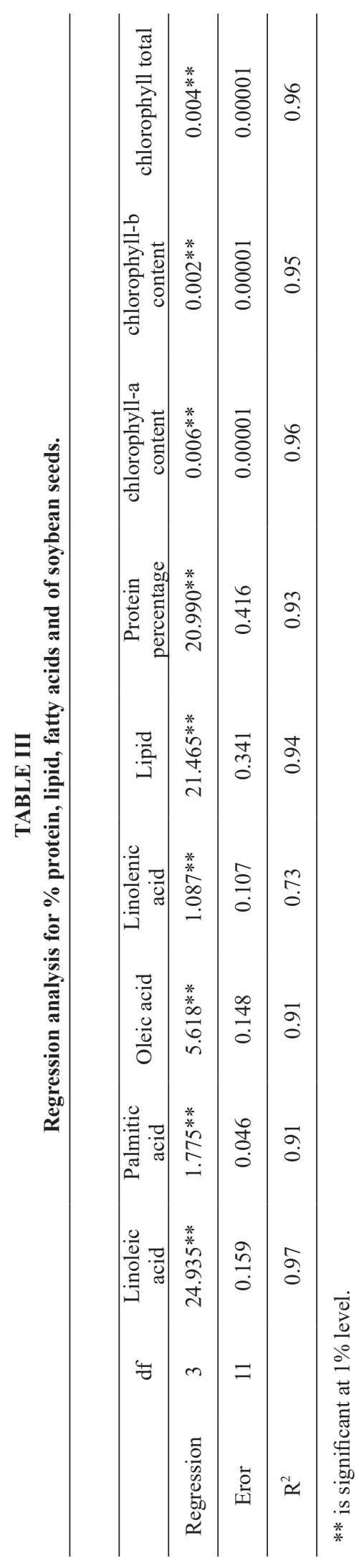


changes in protein contents (Figure 1). This result has conformity with Liu's study (Liu et al. 2005); which they were showed that iron nano-carbonate had positive effect on protein content in peanut. Also the positive effect of iron on protein content have been reported by (Hemantarajan and Trivedi 1997, Rahman 1992) in soybean, (Morshedi 2000, Baybordi and Mamedov 2010) in rape, (Ramesh et al. 1999) in sunflower, (Hemantarajan and Garg 1988) in wheat, (Ravi et al. 2008) in safflower, (Panjtan Doost 1999, Patel et al. 1993) in peanut. Since, iron is one of most important elements that has role in nitrogen fixation so participate in protein procedure (Marschner 1995). The highest percentage of seed's lipid was belonged to $0.75 \mathrm{~g}$ $\mathrm{L}^{-1}$ of nano- $\mathrm{Fe}_{2} \mathrm{O}_{3}$ which had significantly difference from other concentrations and control. The lowest amount of lipid was achieved at control (19.83\%). Foliar spraying with nano- $\mathrm{Fe}_{2} \mathrm{O}_{3}$ were justified the 96 percent of lipid alterations (Figure 2). The positive effects of iron treatment on lipid content have been reported by (Ghasemian 2000, Sakar et al. 1990) in soybean, (Roshdi and Rezadoost 2004) in sunflower, (Morshedi 2000, Baybordi and Mamedov 2010) in rape, (Patel et al. 1993) in peanut, (Ravi et al. 2008) in safflower.

The effect of nano- $\mathrm{Fe}_{2} \mathrm{O}_{3}$ on amount of linolenic acid of soybean seeds was significant at $1 \%$ of probability level (Table III). The most amount of linoleic acid (49.47\%) was observed in $0.75 \mathrm{~g} \mathrm{~L}^{-1}$ of nano- $\mathrm{Fe}_{2} \mathrm{O}_{3}$ that has significantly difference with other treatments and control. The minimum amount of linoleic acid (43.87\%) was belonged to control (Figure 3). The spray of soybeans with nano- $\mathrm{Fe}_{2} \mathrm{O}_{3}$ could justify the 99 percent of changes of linoleic acid. The maximum amount of this fatty acid was related to $0.75 \mathrm{~g} \mathrm{~L}^{-1}$ of nano- $\mathrm{Fe}_{2} \mathrm{O}_{3}$ which has not meaningful difference with $0.50 \mathrm{~g} \mathrm{~L}^{-1}$, but at $1 \%$ of probability level was vary from $0.25,1.0 \mathrm{~g} \mathrm{~L}^{-1}$ and control. The least amount of palmitic acid (10.57) was observed in control treatment (Figure 3). The spray with nano- $\mathrm{Fe}_{2} \mathrm{O}_{3}$ justified $99 \%$ of changes of

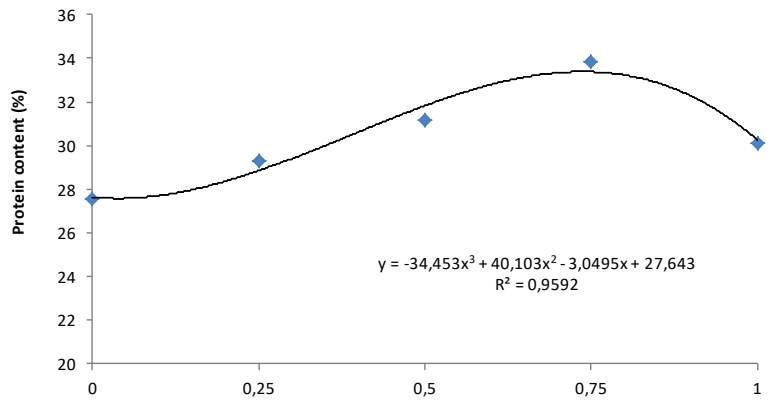

Figure 1 - The effect of different concentrations of nano-iron oxide on soybean seed protein content.

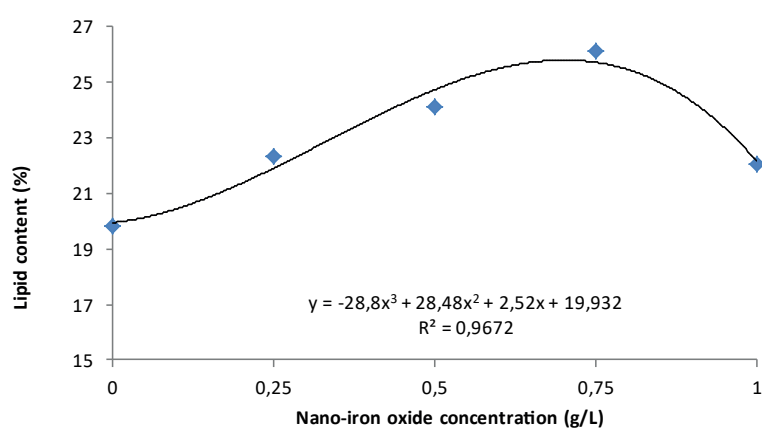

Figure 2- The effect of different concentrations of nano-iron oxide on soybean seed lipid content.

palmitic acid. The regression analysis of data from measurement of oleic acid content showed that the effect of nano- $\mathrm{Fe}_{2} \mathrm{O}_{3}$ on this trait was significant at $1 \%$ of probability level (Table III). Again the maximum amount of oleic acid was belonged to $0.75 \mathrm{~g} \mathrm{~L}^{-1}$ of nano- $\mathrm{Fe}_{2} \mathrm{O}_{3}$ that has significantly difference at $1 \%$ of probability level with other treatments and control. The minimum amount of oleic acid (17.43\%) was obtained in control (Figure $3)$. Foliar spraying of soybean with nano- $\mathrm{Fe}_{2} \mathrm{O}_{3}$ explained 96 percent of changes of oleic acid. The highest amount of linolenic acid was belonged to $0.50 \mathrm{~g} \mathrm{~L}^{-1}$ of nano- $\mathrm{Fe}_{2} \mathrm{O}_{3}$ that has not difference with $0.75 \mathrm{~g} \mathrm{~L}^{-1}$, but has significantly difference at $1 \%$ of probability level with other treatments and control. The lowest amount of this lipid (10.37) was obtained in control that has not difference with 0.25 and $1.0 \mathrm{~g} \mathrm{~L}^{-1}$ (Figure 3). The spray by 

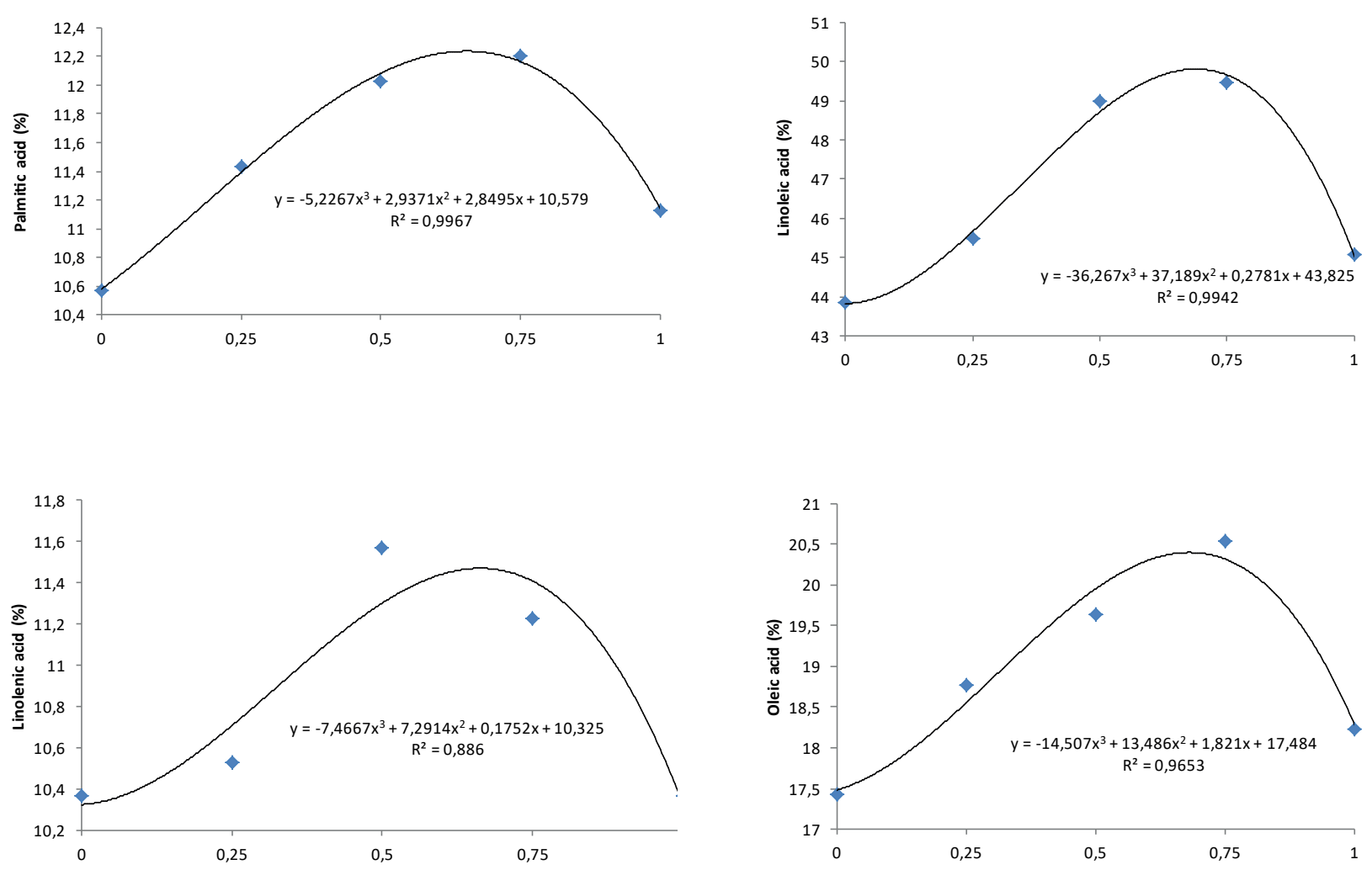

Figure 3 - The effect of different concentrations of nano-iron oxide on soybean seed fatty acids.

nano- $\mathrm{Fe}_{2} \mathrm{O}_{3}$ justified 88 percentages of changes of linolenic acid content.

The results of fitted regression analysis of data from measurement of mineral elements were shown (Table IV). The effect of nano- $\mathrm{Fe}_{2} \mathrm{O}_{3}$ treatment on amount of iron, magnesium, calcium and phosphorus were significant at $1 \%$ of probability level.

The maximum amount of iron was achieved on $0.75 \mathrm{~g} \mathrm{~L}^{-1}$ treatment which has significantly difference with other levels of iron treatment and control. The lowest amount of iron (1.82 $\left.\mathrm{Mg} \mathrm{g}^{-1}\right)$ was belonged to control (Figure 4). Usage of nanoiron oxide solution justified 98 percent of changes of iron content in soybean seeds. The positive effect of iron on increasing iron content was reported in soybean (Rahman 1990, Schenkeveld et al. 2008), sunflower (Roshdi and Rezadoost 2004), rape (Morshedi 2000), and peanut (PanjtanDoost 1999). The most amount of magnesium was achieved by $0.75 \mathrm{~g} \mathrm{~L}^{-1}$ of nano-iron oxide which has significantly difference at $1 \%$ of probability level with other treatment and control. Also the lowest of magnesium content (16.47 $\mathrm{Mg} \mathrm{g}^{-1}$ ) was belonged to control (Figure 4). The foliar spraying of soybean by nano-iron oxide explained 91 percent of changes in magnesium content of seeds. This result has accordance with findings of Panjtan-Doost (1999) that it is about the positive effect of iron on increasing magnesium content of peanut. The maximum amount of storage form of phosphorus was achieved in the treatment of $0.75 \mathrm{~g} \mathrm{~L}^{-1}$ nanoiron oxide that this amount has significantly difference with other treatments and control. The minimum quantity of phosphorous (13.40 $\left.\mathrm{mg} \mathrm{L}^{-1}\right)$ was belonged to control (Figure 4). The spray of soybean by nano-iron oxide solution justified 98 percent of changes of seed phosphorous content. This finding also has accordance with result of Panjtan-Doost (1999) about the positive impact of 
Table IV

Regression analysis for mineral elements of soybean seeds

\begin{tabular}{cccccc}
\hline & $\mathrm{df}$ & $\mathrm{Fe}$ & $\mathrm{Mg}$ & $\mathrm{Ca}$ & $\mathrm{P}$ \\
\hline Regression & 3 & $1.650^{* *}$ & $6.248^{* *}$ & $9.807^{* *}$ & $13.552^{* *}$ \\
Error & 11 & 0.003 & 0.213 & 0.218 & 0.072 \\
$\mathrm{R}^{2}$ & & 0.99 & 0.88 & 0.92 & 0.98 \\
\hline
\end{tabular}

$* *$ is significant at $1 \%$ level.

iron on increasing phosphorous content in peanut kernels. The storage form of phosphorous in seeds is phytic acid (phytin) and it seems that increasing of it, have major efficacy in seeds germination rate. Since phosphorus has important role in supply of energy for growing and dividing cells by oxidative phosphorylation process. The maximum quantity of calcium was obtained in $0.75 \mathrm{~g} \mathrm{~L}-1$ of nano$\mathrm{fe}_{2} \mathrm{O}_{3}$ which has significantly difference at $1 \%$ of probability level with other levels of nano-iron oxide and control. The least amount of calcium (12.33 $\mathrm{Mg} \mathrm{g}^{-1}$ ) was belonged to control (Figure 4). Foliar spraying of soybean by nano-iron oxide explained 93 percent of changes of calcium content in soybean seeds. Panjtan-Doost (1999) was reported that iron has positive impact on increasing of calcium content of peanut kernels. Marschner (1995) wrote that iron had not significant effect on calcium content of soybean seeds, but in this present study we found that iron had positive effect on seeds calcium content.

The amount of chlorophyll-a in soybean seeds showed a significantly difference $(\mathrm{p}>1 \%)$ with nano-iron oxide treatment (Table III). The maximum quantity of chlorophyll-a $(0.190 \mathrm{Mg}$ $\mathrm{g}^{-1}$ ) was achieved in $0.75 \mathrm{~g} \mathrm{~L}^{-1}$ of nano-iron oxide that has significantly difference with other levels of nano- $\mathrm{Fe}_{2} \mathrm{O}_{3}$ and control. The minimum amount of chlorophyll-a (0.090 $\left.\mathrm{Mg} \mathrm{g}^{-1}\right)$ was belonged to control (Figure 5). Usage of nano-iron oxide solution explained 93 percent of changes of chlorophyll a content in soybean seeds. In attention to regression equation it is observed that the maximum amount of chlorophyll-a $\left(0.211 \mathrm{Mg} \mathrm{g}^{-1}\right)$ was obtained by usage of $0.78 \mathrm{~g} \mathrm{~L}^{-1}$ of nano-iron oxide.

The amount of chlorophyll-b in soybean seeds showed a significantly difference $(\mathrm{p}>1 \%)$ with nanoiron oxide treatment (Table III). The maximum quantity of chlorophyll-b was achieved in $0.75 \mathrm{~g} \mathrm{~L}^{-1}$ of nano-iron oxide that has significantly difference with other levels of nano- $\mathrm{Fe}_{2} \mathrm{O}_{3}$ and control. The minimum amount of chlorophyll-a $\left(0.033 \mathrm{Mg} \mathrm{g}^{-1}\right)$ was belonged to control (Figure 5). Usage of nanoiron oxide solution explained 93 percent of changes of chlorophyll-b content in soybean seeds. In attention to regression equation it is observed that the maximum amount of chlorophyll-b $(0.063 \mathrm{Mg}$ $\left.\mathrm{g}^{-1}\right)$ was obtained by usage of $0.57 \mathrm{~g} \mathrm{~L}^{-1}$ of nanoiron oxide.

The amount of total chlorophyll content in soybean seeds showed a significantly difference ( $\mathrm{p}>1 \%$ ) with nano-iron oxide treatment (Table III). The maximum quantity of total chlorophyll was achieved in $0.75 \mathrm{~g} \mathrm{~L}^{-1}$ of nano-iron oxide that has significantly difference with other levels of nano$\mathrm{Fe}_{2} \mathrm{O}_{3}$ and control. The minimum amount of total chlorophyll (0.142 $\left.\mathrm{Mg} \mathrm{g}^{-1}\right)$ was belonged to control (Figure 5). Usage of nano-iron oxide solution explained 89 percent of changes of total chlorophyll content in soybean seeds. In attention to regression equation it is observed that the maximum amount of total chlorophyll $\left(0.188 \mathrm{Mg} \mathrm{g}^{-1}\right)$ was obtained by usage of $0.59 \mathrm{~g} \mathrm{~L}^{-1}$ of nano-iron oxide. 

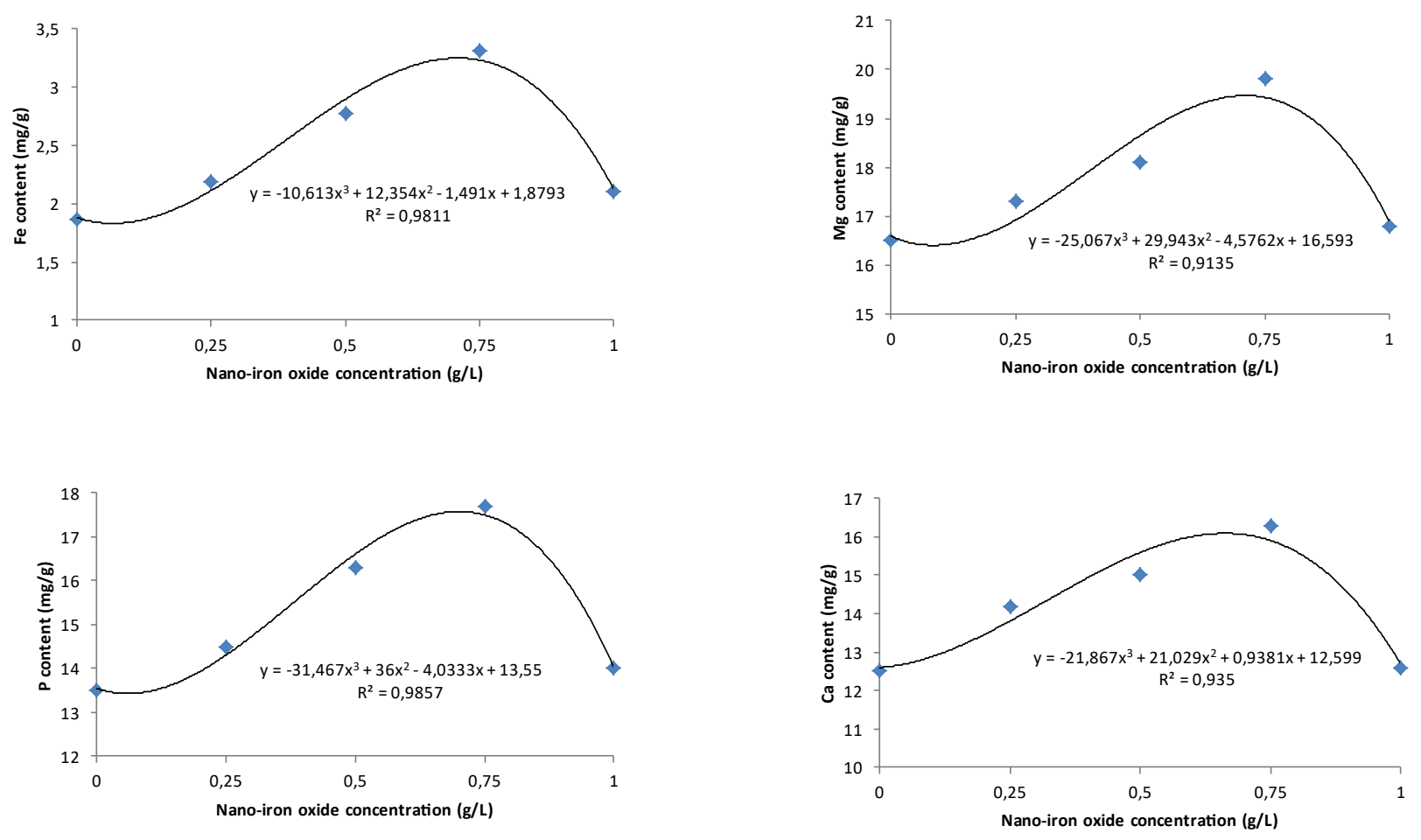

Figure 4 - The effect of different concentrations of nano-iron oxide on soybean seed mineral content.
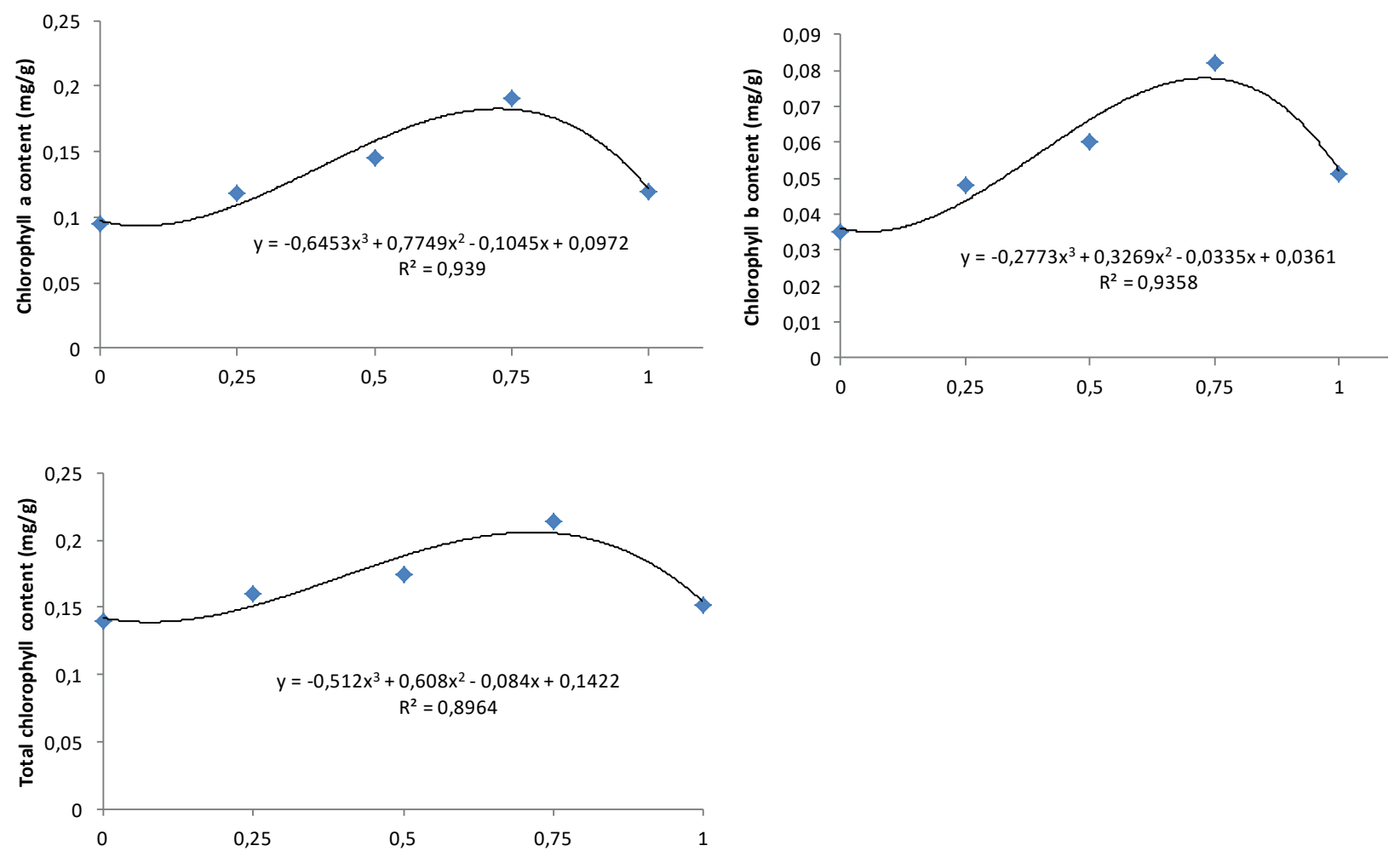

Figure 5 - The effect of different concentrations of nano-iron oxide on soybean seed chlorophyll content. 


\section{CONCLUSIONS}

The obtained results from this study indicate that the foliar spraying of soybean plants by $0.75 \mathrm{~g} \mathrm{~L}^{-1}$ of nano-iron oxide leads to enhancement in protein (up to $33.83 \%$ ) and lipid (up to $25.40 \%$ ) percentage in contrast of control treatment. The highest rate of oleic acid (20.45\%) and linoleic acid (49.47\%) were observed in treatment of $0.75 \mathrm{~g} \mathrm{~L}^{-1}$ of nanoiron oxide that had significantly difference with other treatment and control. Also the highest rate of linolenic acid (11.43\%) was belonged to 0.50 $\mathrm{g} \mathrm{L}^{-1}$ which had not difference with $0.75 \mathrm{~g} \mathrm{~L}^{-1}$ of nano- $\mathrm{Fe}_{2} \mathrm{O}_{3}$ but was vary from other treatments of nano-iron oxide and control. According to results of this experiment, it is distinguished that using of nano-iron oxide has a positive effect on seed quality. In conclusion, increasing of chlorophyll contents in soybean seed could have an antioxidant role in soybean oil and make favorable nutritional effects from the point of view in food science and technology.

\section{REFERENCES}

ANONYMOUS. 2014. A guide to kjeldahl nitrogen determination methods and apparatus. LABCONCO. Texas. USA. Accessed online at www.ExpotechUSA.com. AOAC - ASSOCIATION OF OFFICIAL ANALYTICAL CHEMISTS. 1990. Official Methods of Analysis. $15^{\text {th }}$ ed., Arlington, VA.

AZADMARD-DAMIRCHI S AND DUTTA PC. 2008. Stability of minor lipid components with emphasis on phytosterols during chemical interesterification of a blend of refined olive oil and palm stearin. J AOCS 85: 13-21.

BAYBORDI A AND MAMEDOV. G. 2010. Evaluation of application methodesfor efficiency of zinc and iron for Canola (Brssica napus L.). Not Sci Biol 2(1): 94-103.

BURKE DJ, PIETRASIAK N, SITU SF, ABENOJAR EC, PORCHE M, KRAJ P, LAKLIANG Y AND SAMIAACS. 2015. Iron oxide and titanium dioxide nanoparticle effects on plant performance and root associated microbes. Int $\mathrm{J}$ Mol Sci 16: 23630-23650.

CHONKAR AK AND CHANDEL AS. 1991. Effect of iron and molybdenum on nitrogenase activity and nitrogen fixation in soybean (Glycin max L.) grown in Alluval soils of North India. Indian J Agron 36: 124-128.
FATHI-ACHACHLOUEI B. AND AZADMARDDAMIRCHI. 2009. Milk thistle seed oil constituents from different varieties grown in Iran. J AOCS 86: 643-649.

GHASEMIAN V. 2000. The effect of micronutrients iron, zinc and manganese on soybean seed quality and quantity in western Azerbaijan. Ms.C Thesis. Tarbiat Modares University. Iran. (Unpublished).

HEMANTARAJAN A AND GARG OK. 1988. Iron and zinc fertilization with refrence to the grain quality of Triticum aestivum L. J Plant Nutr 11(6): 1439-1450.

HEMANTARAJAN A AND TRIVEDI AK. 1997. Growth and yield of soybean as influenced by sulphur and iron nutrition. Indian J Plant Phys 2: 304-306.

LICHTENTHALER HK. 1987. Chlorophylls and carotenoids: Pigments of photosynthetic biomembranes. Methods Enzymol 148: 350-382.

LINDSAY WL AND NORVELL WA. 1978. Development of a DTPA test for zinc, iron, manganese, and copper. Soil Sci Soc Am J 42: 421-426.

LIU XM, ZHANG FR, FENG ZB, ZHANG SHQ, HE XSH, WANG R AND WANG. Y. 2005. Effects of nano-ferric oxide on the growth and nutrients absorption of peanut. Plant Nutr Ferti Sci 11: 14-18.

MALAKOUTI M AND TEHRANI M. 2005. Micronutrient role in increasing yield and improving the quality of agricultural products. $1^{\text {st }}$ ed., Tarbiat Modarres University in Tehran press, $299 \mathrm{p}$.

MARSCHNER H. 1995. Mineral nutrition of higher plants. $2^{\text {nd }}$ ed., Academic Press Inc, London.

MENGEL K. 1991. Ernahrung und Stoffwechsel der Pflanze. Spektrum Akademischer Verlag Press.

MORALES F, ABADIA A AND ABADIA J. 1990. Characterization of the xanthophylls cycle and other photosynthetic pigment changes by iron deficiency in Sugar beet (Beta vulgaris L.). Plant Physiol 94: 667-613.

MORSHEDI A. 2000. The effect of foliar application on yield, quality and enrichment of canola seed. Ms.C Thesis. Tarbiat Modares University. Iran. (Unpublished).

PANJTAN-DOOST M. 1999. Effect of iron on the quantity and quality of peanuts (Arachis Hypogaea L.) in Gilan province. Ms.C thesis. Tarbiat Modares University. Iran. (Unpublished).

PATEL MS, SUTAR DM AND KANIZARIA MV. 1993. Effect of foliar application of iron and sulfur in curing chlorosis in Groundnut. J Soc Ind Soil Sci 41(1): 103-105.

RAHMAN MM. 1992. Effect of micronutrient on the growth and yield of soybean plants. $4^{\text {th }}-5^{\text {th }}$ Bangladesh science conference, p. 122.

RAMESH S, RAGHBIR S, MOHINDER S, SHARMA R, SINGH R AND SINGH M. 1999. Effect of P and Fe on the yield of Sunflower. Ann Agri Res 4(2): 145-150.

RAVI S, CHANNAL HT, HEBSUR NS, PATIL BN AND DHARMATTI PR. 2008. Effect of sulfur, zinc and iron 
nutrition on growth, yield, nutrient uptake and quality of Safflower (Carthamus tinctorius L.). Karnataka J Agri Sci 21(3): 382-385.

RONAGHI A AND GHASEMI-FASAEI R. 2007. Field evaluations of yield, iron-manganese relationship, and chlorophyll meter readings in soybean genotypes as affected by iron-ethylenediamine di-o-hydroxyphenylacetic acid in a Calcareous soil. J Plant Nutr 31(1): 81-89.

ROSHDI M. AND REZADOOST S. 2004. Effect of potassium and micronutrients on the iron on quantitative and qualitative characteristics of sunflower cropping. In: Proceedings of the $8^{\text {th }}$ Iranian Crop Science Congress, 2527 August, Gilan University, p. 69-73.

SAKAR MT, LEILA AA AND HELALY MNM. 1990. Physiological studies on soybean as affected by certain growth substances and micronutrients. J Agri Sci 13: 613622.

SCHENKEVELD WDC, DIJCKER R, REICHWEIN AM, TEMMINGHOFF EJM AND VAN RIEMSDIJK WH. 2008. The effectiveness of soil-applied FeEDDHA treatments in preventing iron chlorosis in soybean as a function of the o,o-FeEDDHA content. Plant Soil 303(12): 161-176.

SEDGHI M, SHAKIBA MR, ALYARI H, JAVANSHIR A AND VALIZADEH M. 2005. Effect of rhizobia, nitrogen and weeds on soybean grain protein and oil content. Turkish J Field Crops 10(22): 64-72.

TERRY RE AND JOLLEY VD. 1994. Nitrogenase activity is required for activation of iron-stress response in iron inefficient T203 Soybean. J Plant Nutr 17: 1417-1428. 